\section{BDA Report and Financial Statements 2016 - update}

Volume 222 No. 821 April issue of the BDJ included the Association's statutory accounts for the year ending September 2016. At the AGM held on 25 May 2017, a query was raised with regards to the 2015 directors' remuneration figures found in note 6 .

Although the correct disclosure was previously audited and made available to the public in the 2015 statutory accounts, please find below the corrected historic disclosure. The auditors have advised that they do not need to re-date the audit opinion or have it reaffirmed.

6

$\begin{array}{lll}\text { Directors } & \mathbf{2 0 1 6} & \mathbf{2 0 1 5} \\ \text { Directors' remuneration consists of: } & \mathbf{f} & \mathbf{f} \\ \text { Stipend payments } & 330,000 & 330,000\end{array}$

There were no (2015 - Nil) directors in the company who were considered to be salaried, full-time executive directors during the year.

The total amount payable to the highest paid director in respect of emoluments was $£$ Nil (2015 - £Nil).

\begin{tabular}{lll} 
Stipend payments & \multicolumn{2}{c}{} \\
& $\mathbf{f}$ & $\mathbf{2 0 1 5}$ \\
M Armstrong & 75,000 & $\mathbf{f}$ \\
P Blaylock & 15,000 & 75,000 \\
V Chan & 15,000 & 15,000 \\
E Crouch & 37,500 & 15,000 \\
L D'Cruz & 15,000 & 29,077 \\
M Fallowfield & - & 11,250 \\
T Harker & 15,000 & 3,750 \\
P Henderson & 15,000 & 15,000 \\
J Husband & 37,500 & 15,000 \\
N Jones & 15,000 & 32,820 \\
R Kinloch & 15,000 & 15,000 \\
R Ladwa & 15,000 & 28,103 \\
A Lockyer & 15,000 & 15,000 \\
S Sanderson & 3,750 & 15,000 \\
S Shimberg & 15,000 & 15,000 \\
G Stokes & - & 15,000 \\
J Stokes & 15,000 & 3,750 \\
P Woodhouse & 11,250 & 11,250 \\
& & -
\end{tabular}

\section{ADI Young Dentist Day}

This year's Association of Dental

Implantology (ADI) Young Dentist Day will be held on Saturday 2 September 2017 at IET London: Savoy Place. The event will provide young dentists with further information about implant dentistry, including ways in which they can become involved in implantology safely.

In the morning, there will be quick-fire presentations on the history, available training pathways, case assessment, basics of surgery, and restoration of implants.

In the afternoon the delegates will divide into groups for the workshops and experience first-hand what they have learned about in the morning lectures.

The event is open to ADI First Five Years and Student members. To book a place visit http://www.adi.org.uk/events/ ydd17/.

\section{Christmas issue 2017 - call for}

\section{content}

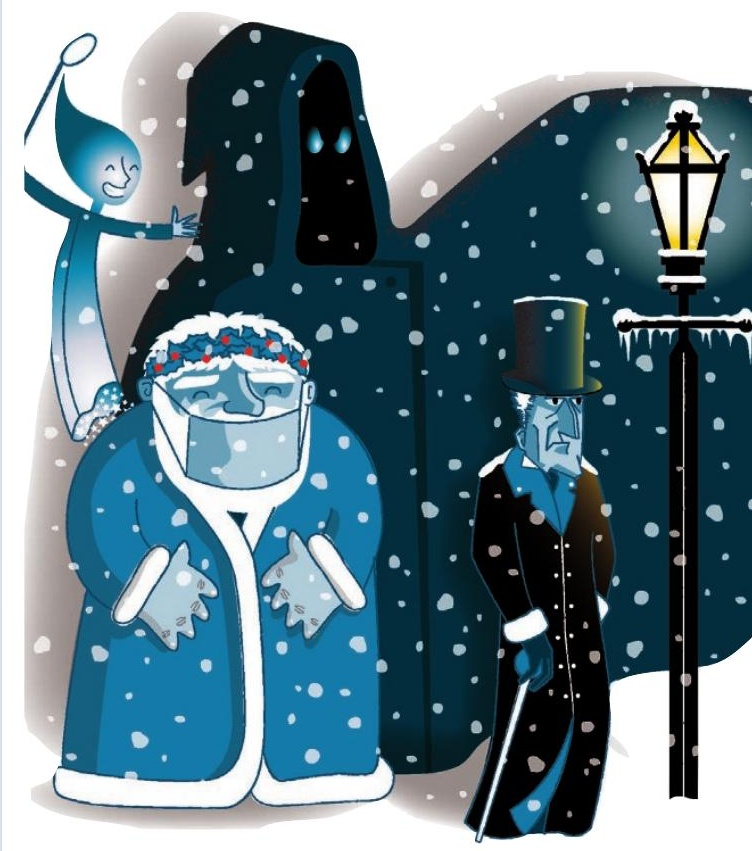

The BDJ editorial team would like to invite writers with a flair for satire or penchant for the tongue-in-cheek to submit content for this year's Christmas issue.

The first BDJ Christmas issue was published in December 2016 (Volume 221 issue 12), featuring the research paper What's in a name? Nominative determinism in the UK dental workforce (http://go.nature.com/2rPjZH9); letters to the editor such as Infection control: Mistletoe threat; news feature Study examines the gingivae of gummy bears; and in the products section, Mouth protection for your 147 and Diamante filling material.

The special feature A Christmas story for the chairside, written by Editor-in-Chief Stephen Hancocks OBE, was also published in December 2016 (http://go.nature. com/2hYOFln), retelling Dickens' novella A Christmas Carol.

If you have an idea for a spoof $B D J$ paper, we would like to hear from you. Please email us a description of your proposed topic by 31 August 2017. We are pleased to consider all kinds of articles, and a Christmas theme is not required.

To submit a proposal or for further information, please email Senior Managing Editor Dr Ruth Doherty on r.doherty@nature.com. 